\title{
Diyarbakır İli Eğil İlçesi Kıraç Meralarının Botanik Kompozisyonunun Belirlenmesi
}

\author{
Seyithan SEYDOŞOĞLU ${ }^{1 *}$, Veysel SARUHAN ${ }^{2}$, Ali MERMER ${ }^{3}$ \\ ${ }^{I}$ GAP Uluslar Arası Tarımsal Araşttrma ve Eğitim Merkezi Müdürlüğ̈̈, Diyarbakır, TÜRKIYYE \\ ${ }^{2}$ Dicle Üniversitesi, Ziraat Fakültesi, Tarla Bitkileri Bölümü, Diyarbakır, TÜRKIYY \\ ${ }^{3}$ Tarla Bitkileri Merkez Araştrma Enstitüsü Müdürlüğü, Coğrafi Bilgi Sistemleri ve Uzaktan Algllama Bölümü, Ankara, TÜRKIYE
}

Geliş Tarihi/Received: 11.02 .2015

Kabul Tarihi/Accepted: 07.09.2015

"Sorumlu Yazar/Correspondence: ege_university47@hotmail.com

Özet: Bu araştırma, Diyarbakır ili Eğil ilçesinin kıraç kesimindeki 5 farklı merada, vejetasyon yapısının belirlenmesi amacıyla yürütülmüştür. Araştırmada, her merada toplam 4 lup hattındaki 400 noktada ölçüm yapılarak meradaki bitkilerin türleri, cins ve familyaları, etkileri (azalıcı, çoğalııı, istilacı), ömür uzunlukları, meraların bitki ile kaplı alan oranları ve türlerin botanik kompozisyondaki oranları saptanmıştır. Araştırmada, 10 bitki familyasının 27 farklı cinsinden 35 bitki türünün tespiti yapılmıştır. İncelenen meralarda bitki ile kaplılık oranlarının \% 26.60-60.36, botanik kompozisyondaki buğdaygillerin oranının \% 27.81-37.45, baklagillerin oranının \% 8.67-39.31, diğer familya bitkilerinin oranının ise \% 23.2459.16 arasında değiştiği saptanmıştır. Araştırmada, incelenen mera vejetasyonlarının tamamının istilacı türlerden oluştuğu belirlenmiştir.

Anahtar Kelimeler: Mera, bitki ile kaplı alan, botanik kompozisyon, lup metodu

\section{Determination of the Botanical Composition of the Arid Pasture in District Eğil, Diyarbakır}

\begin{abstract}
This research was conducted to determine vegetation structures of the native pastures in the five villages of district Eğil, Diyarbakır. Vegetations of the pastures were studied by the Loop Method. In each pasture 400 loop measurements in 4 lines were made. Plant-covered area rate, botanical composition in the plant covered area was calculated from the loop measurements. In the research, 35 plant species from 27 different genera of 10 plant families were obtained. As depending on the pastures, plant cover percentages varied between $26.60 \%$ to $60.36 \%$ and botanical composition rate of grasses, legumes and other family plants in the total plant cover varied between $27.81 \%$, and $37.45 \%, 8.67 \%$, and $39.31 \%$, $23.24 \%$, and $59.16 \%$, respectively. The investigation, it was concluded that vegetations of the pastures were all composed of invader plants.
\end{abstract}

Keywords: Pasture, plant coverage, botanical composition, loop method

\section{Giriş}

Meraların büyük çoğunluğunun kurak ve yarı kurak yağış kuşağında yer alması ve yağışın düşüklüğü ile birlikte amenajman ilkelerine uyulmadan yapılan ağır otlatma, meralarda bitki örtüsünün bozulmasının en önemli sebeplerindendir (Holechek ve ark., 2004). Bu nedenle bir taraftan otlatmayı kontrol altına alarak uygun kullanımı sağlamak, diğer taraftan vejetasyonları uygun metotlarla ıslah etmek gerekmektedir (Çomaklı ve Menteşe, 1999; Altın ve ark., 2005). Ayrica sürülüp tarla arazisine dönüştürülen ve verimliliklerini kaybettikten sonra terk edilen mera alanlarının yeniden bitki örtüsüne 
kavuşturulması ve hayvancılığın hizmetine sunulması için çeşitli tedbirlerin alınması gerekmektedir.

Mera 1slahı; yem kaynaklarını ıslah etmek veya bu yemi otlayan hayvanların yararlanmalarını kolaylaştırmak için, mera üzerinde özel işlemlerin uygulanması, geliştirici tedbirlerin alınması ve bazı tesislerin yapılması olarak tanımlanır. Islahta hedeflenen başarıya ulaşabilmenin ilk şartı eldeki materyalin iyi tanınmasına bağlıdır. Bu nedenle, farklı iklim ve toprak şartlarında bulunan meralar hakkında çeşitli bilgilere sahip olunması gerekmektedir. $\mathrm{Bu}$ amaçla meralar üzerinde yapılan çalışmalar iki grup altında incelenebilmektedir. Bunlar; çayır-mera vejetasyonunun etüdü ve mera verimliliğinin ölçülmesi, yani mera durumunun belirlenmesi ve durumu tespit edilen meraların çeşitli ıslah yöntemleri (dinlendirme, gübreleme ve yabancı ot kontrolü v.s.) ile iyileştirilmesidir (Uslu, 2005).

Mera botanik kompozisyonu ve hâkim bitki türleri, bu meraların hâlihazırdaki sınıflandırılması ve kalite değerinin anlaşılması önemli olduğu kadar, zaman içerisinde meralardaki nitelik ve nicelik değişimlerinin belirlenmesi de son derece önem taşımaktadır. Kıraç mera alanında tür değişiminin tespit edilmesi problemli alanların ve erozyon riski taşıyan meraların kesin olarak belirlenmesine yardımcı olacak, toplanan veriler mera alanlarının ıslahına temel oluşturacak ve bir sonraki çalışmalarda değişimininin boyutları daha iyi ortaya konulabilecektir. $\mathrm{Bu}$ nedenle, bu çalışma Diyarbakır iline bağlı Eğil ilçesinde bulunan kıraç meraların durumunun ve meraların temel özelliklerinden biri olan bitki ile kaplı alanın ve bu alan içerisinde bitkilerin bulunma oranlarının belirlenmesi amacıyla yapılmıştır.

\section{Materyal ve Yöntem}

Araştırmada vejetasyon etütleri, Diyarbakır ili Eğil ilçesine bağlı Ayalı, Baysu, Kalkan, Konak ve Selman köylerine ait 5 farklı kıraç merada (Şekil 1), 15 Nisan-15 Haziran 2014 tarihleri arasinda yürütülmüştür. İncelenen meralar; kuraklık indeksi, bakı ve rakım bakımından nispeten aynı homojen alanda (Avağ ve ark., 2012) yer almıştır.

Eğil ilçesi, Diyarbakır merkezinin kuzeyindeki dağlık bir arazide kurulmuş olup, yaklaşık 450 $\mathrm{km}^{2}$ 'lik bir yüzölçümüne sahiptir. Diyarbakır'a 50 km uzaklıkta olan ilçenin kuzeyinde Dicle Nehri (Dicle Baraj Gölü) ve Dicle ilçesi, doğusunda Hani ve Hazo ilçeleri, batısında ise Ergani ilçesi yer almaktadır. Denizden yüksekliği $825 \mathrm{~m}$ olan ilçenin iklimi karasal iklim olup, yazları sıcak ve kurak, kışları soğuk ve yağışlı geçmektedir (Değirmenci Karataş ve ark., 2015).

Meralarının botanik kompozisyonunu belirlemek için modifiye edilmiş Tekerlekli Lup (halka) Metodu kullanılarak (Koç ve Çakal, 2004), toplamda 56 durakta vejetasyon etüdü yapılmıştır. Vejetasyon etüdü meradaki hâkim bitkilerin

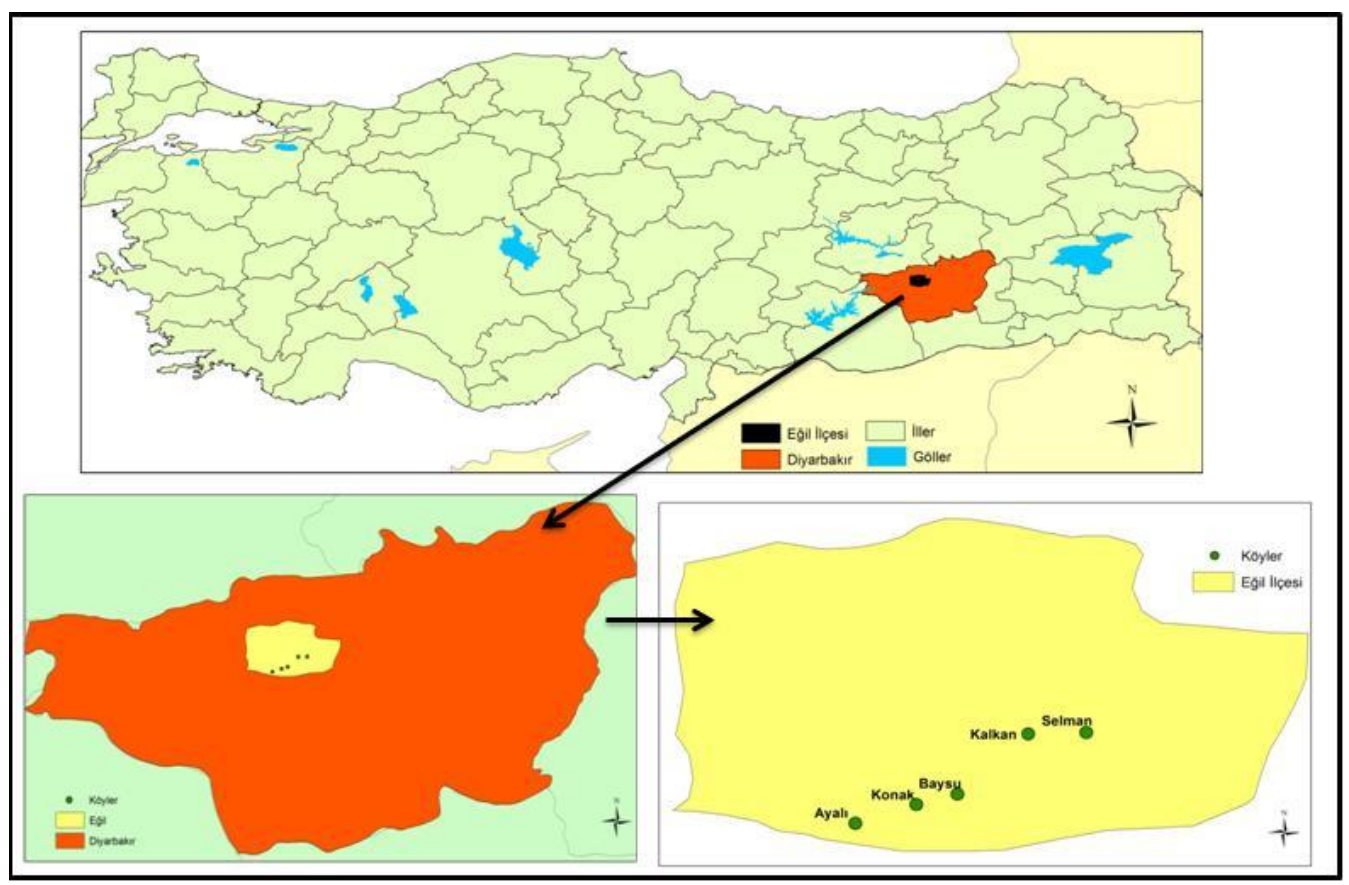

Şekil 1. Diyarbakır ili Eğil ilçesi vejetasyon etüdü yapılan duraklar 
çiçeklendiği dönemde, her durakta 4 hatta toplam 400 noktada; doğu, batı, kuzey ve güney yöneyleri esas alınarak, bitki okunmak suretiyle yapılmıştır. Okunan her bir bitki türüne ait değerler toplam bitki sayısına oranlanarak türlerin botanik kompozisyondaki oranları tespit edilmiştir. Mera kesimlerinde, bitki örtüsünün toprağı kaplama oranı vejetasyon etüdü sırasında bitkiye rastlanan nokta sayısının ölçülen toplam nokta sayısına oranlanması ile belirlenmiştir. İncelenen meralarla ilgili olarak; bitki ile kaplı alan oranı (\%), alana göre botanik kompozisyon oranları (\%), Gökkuş ve ark. (2000) tarafından açıklanan yöntemlere göre saptanmıştır.

Alınan bitki örnekleri; Hitchcock (1950), Edgecombe (1964), Garms ve ark. (1968), Pohl (1968), Davis (1969), Polunin ve Huxley (1974), Huxley ve Taylor (1977), Christiansa ve Hoen (1979), Weymer (1981), Demiri (1983), Öztan ve Okatan (1985), Needon ve ark. (1989) ve Kürschner ve ark. (1995)'nın eserlerinden yararlanılarak teşhis edilmiştir. Tanımlanan bitkilerin Türkçe isimleri Anonim (2008)'e göre yazılmıştır.

Araştırmadan elde edilen verilere JUMP istatistik paket programı yardımıyla tesadüf blokları deneme desenine göre 4 tekerrürlü olarak varyans analizi yapılmış, bitki ile kaplı alan ve botanik kompozisyon verilerine varyans analizi uygulanmadan önce açı transformasyonu (Yurtsever, 1984) uygulanmıştır.

\section{Bulgular ve Tartışma}

Araştırmada incelenen Diyarbakır ili Eğil ilçesine bağlı 5 köy merasında tespit edilen türler, familyalar, türlerin ömür uzunlukları, etkileri ve botanik kompozisyondaki oranları Tablo 1'de verilmiştir.

Etüt yapılan meralardan Ayalı köyü merasında, 1 buğdaygil, 3 baklagil, 3 diğer familya türlerinden olmak üzere toplam 7 bitki türü tespit edilmiştir. Tespit edilen bitki türlerinin 1 adedinin tek-çok yıllık, 6 adedinin ise tek yıllık olduğu saptanmıştır. Baysu köyü merasında 3 buğdaygil, 1 baklagil, 7 diğer familya türlerinden olmak üzere toplam 11 bitki türü tespit edilmiş, tespit edilen bitki türlerinin 4 adedinin çok yıllık, 7 adedinin tek yıllık tür olduğu belirlenmiştir. Kalkan köyü merasında, 3 buğdaygil, 3 baklagil, 7 diğer familya türlerinden olmak üzere toplam 13 bitki türü saptanmış, türlerin 1 adedinin tek-çok yıllık, 12 adedinin ise tek yıllık olduğu görülmüştür. Konak köyü merasında 1 buğdaygil, 3 baklagil, 4 diğer familya türlerinden olmak üzere 8 bitki türü tespit edilmiş, bitki türlerinin 1 adedinin tek-çok yıllık, 7 adedinin tek yıllık tür olduğu belirlenmiştir. Selman köyü merasında ise, 3 adet buğdaygil, 2 adet baklagil ve 5 adet diğer familya türlerinden olmak üzere toplam 10 bitki türü tespit edilmiş, tespit edilen bitki türlerinin, 1 adedinin çok yıllık, 1 adedinin iki yıllık, 8 adedinin ise tek yıllık olduğu saptanmıştır (Tablo 1).

Araştırmada incelenen 5 farklı merada; toplam 10 farklı bitki familyasından, 27 farklı cinse ait toplam 35 farklı bitki türüne rastlanmıştır (Tablo 1). Trabzon'da yapılan çalışmada Okatan (1987) 124, Erzurum'da yapılan çalışmada ise Bakoğlu ve Koç (2002) 90, bitki taksonuna rastlamışlardır. Diyarbakır'da 15 yıldır korunan bir mera ile otlatma baskısı altındaki bir merayı karşılaştırmak amacıyla yürütülen çalışmada; toplam 12 familyaya ait 41 cins ve bu cinslere ait 51 tür tespit edildiği, bunlardan 11 familya 26 cins ve 33 türün korunan alanda, 6 familya 19 cins ve 19 türün ise otlanan alanda yer aldığı bildirilmektedir (Başbağ ve Çelik, 2001). Babalık ve Sönmez (2010) Isparta ili Bozanönü köyü Kırtepe merasında yaptıkları araştırmalarında, 32 familyaya ait 107 cins ve 129 bitki taksonu belirlendiğini bildirmektedirler.

Eğil ilçesi kıraç meralarında belirlenen türlerin tamamının De Vries ve ark. (1951)'na göre istilacı tür olduğu belirlenmiştir (Tablo 1). İstilacı tür olarak öne çıkan bitkiler; pisipisi arpası (Hordeum murinum), narin dercikotu (Torilis leptocarpa), anadolu üçgülü (Trifolium resupinatum) ve dam bromu (Bromus tectorum) olduğu tespit edilmiştir. Samsun meralarında yapılan bir çalışmada (Yavuz ve ark., 2011), toplam 207 tür tespit edilmiş, bu türlerin 35 tanesi azalıcı, 21 tanesini çoğalıcı ve 151 tanesi de istilacı tür olarak belirlenmiştir. Yavuz ve ark. (2012) Amasya ili meralarında yaptıkları araştırmalarında; tespit edilen türlerin 34 tanesinin azalıcı, 19 tanesinin çoğalıcı ve 133 tanesinin de istilacı tür olduğunu; botanik kompozisyondaki oranları itibariyle istilacı türler içerisinde öne çıkan türlerin sırasıyla, Medicago minima (\% 5.24), Trifolium striatum (\% 2.93), Eryngium campestre (\% 2.56), Taraxacum bessarabicum (\% 2.53) olarak belirlendiğini bildirmektedirler.

İncelenen meralarda, bitki ile kaplı alan oranları ve botanik kompozisyondaki familyaların oranları Tablo 2'de görülmektedir. Araştırmada elde edilen sonuçlara göre, vejetasyon etüdü yapılan 5 farklı merada bitki ile kaplı alan oranı \% 26.60-60.36 arasında değişmiş ve bu değişim istatistiksel olarak önemli olduğu ortaya çıkmıştır. En yüksek bitki ile kaplı alan oranı \% 60.36 ile Baysu köyü merasında, en düşük bitki ile kaplı alan oranı ise \% 26.60 ile Kalkan köyü merasında saptanmıştır. Baysu köyü merasında bitki ile kaplı 
Tablo 1. İncelenen meralarda tespit edilen türlerin familyaları, ömür uzunlukları, etkileri ve botanik kompozisyondaki oranı

\begin{tabular}{|c|c|c|c|c|}
\hline Tür adı & Familya & Ömrü & Etki & $\begin{array}{l}\text { Botanik } \\
\text { kompozisyondaki } \\
\text { oran1 }(\%)\end{array}$ \\
\hline \multicolumn{5}{|c|}{ Ayalı köyü } \\
\hline Centaurea iberica & Asteraceae & Tek -Çok Yıllık & İstilac1 & 8.0 \\
\hline Hordeum murinum & Poaceae & Tek Y1llık & İstilac1 & 40.6 \\
\hline Trifolium resupinatum & Fabaceae & Tek Y1llık & İstilac1 & 29.2 \\
\hline Trifolium nigrescens & Fabaceae & Tek Y1llık & İstilac1 & 5.6 \\
\hline Notobasis syriaca & Asteraceae & Tek Y1llık & İstilac1 & 6.6 \\
\hline Trifolium globosum & Fabaceae & Tek Yıllık & İstilac1 & 7.6 \\
\hline Erysimum repandum & Brassicaceae & Tek Yillık & İstilac1 & 2.4 \\
\hline \multicolumn{5}{|c|}{ Baysu köyü } \\
\hline Astragalus plumosus & Fabaceae & Çok Yillık & İstilac1 & 2.3 \\
\hline Bombycilae naerecta & Asteraceae & Tek Yıllık & İstilacı & 5.1 \\
\hline Bromus tectorum & Poaceae & Tek Yillık & İstilacı & 20.4 \\
\hline Carduus pycnocephalus & Asteraceae & Tek Yillık & İstilacı & 4.3 \\
\hline Eryngium campestre & Umbelliferae & Çok Yillık & İstilac1 & 2.7 \\
\hline Euphorbia macroclada & Euphorbiaceae & Çok Yillık & İstilac1 & 3.0 \\
\hline Hirschfeldia incana & Brassicaceae & Tek Y1llık & İstilac1 & 11.4 \\
\hline Trachynia distachya & Poaceae & Tek Yıllık & İstilac1 & 5.0 \\
\hline Rostraria cristata & Poaceae & Tek Yillık & İstilac1 & 3.3 \\
\hline Torilis leptocarpa & Umbelliferae & Çok Yillık & İstilac1 & 34.8 \\
\hline Pimpinella eriocarpa & Umbelliferae & Tek Yillık & İstilac1 & 7.7 \\
\hline \multicolumn{5}{|c|}{ Kalkan köyü } \\
\hline Astragalus hamosus & Fabaceae & Tek Yıllık & İstilacı & 3.4 \\
\hline Bromus scoparius & Poaceae & Tek Yıllık & İstilacı & 1.9 \\
\hline Capsella bursa-pastoris & Brassicaceae & Tek Yıllık & İstilac1 & 10.3 \\
\hline Centaurea iberica & Asteraceae & Tek- Çok Yıllık & İstilacı & 4.4 \\
\hline Crepis sancta & Asteraceae & Tek Yıllık & İstilacı & 7.5 \\
\hline Erodium cicutarium & Geraniaceae & Tek Yıllık & İstilacı & 1.3 \\
\hline Hirschfeldia incana & Brassicaceae & Tek Yıllık & İstilacı & 1.3 \\
\hline Hordeum murinum & Poaceae & Tek Yıllık & İstilacı & 18.8 \\
\hline Malva neglecta & Malvaceae & Tek Yıllık & İstilacı & 2.2 \\
\hline Trifolium resupinatum & Fabaceae & Tek Yillık & İstilacı & 29.8 \\
\hline Trifolium nigrescens & Fabaceae & Tek Yillık & İstilacı & 13.2 \\
\hline Erysimum repandum & Brassicaceae & Tek Yıllık & İstilac1 & 3.4 \\
\hline Vulpia myuros & Poaceae & Tek Yillik & İstilac1 & 2.5 \\
\hline \multicolumn{5}{|c|}{ Konak köyü } \\
\hline Anthemis cotula & Asteraceae & Tek Yillık & İstilac1 & 1.9 \\
\hline Capsella bursa-pastoris & Brassicaceae & Tek Y1ll1k & İstilac1 & 8.9 \\
\hline Centaurea iberica & Asteraceae & Tek-Çok Y1llık & İstilac1 & 7.0 \\
\hline Helianthemum ledifolium & Cistaceae & Tek Y1llık & İstilacı & 4.7 \\
\hline Hordeum murinum & Poaceae & Tek Yıllık & İstilacı & 35.1 \\
\hline Trifolium scabrum & Fabaceae & Tek Yıllık & İstilacı & 10.2 \\
\hline Trifolium nigrescens & Fabaceae & Tek Yıllık & İstilacı & 27.1 \\
\hline Trifolium bullatum & Fabaceae & Tek Yillık & İstilac1 & 5.1 \\
\hline \multicolumn{5}{|c|}{ Selman köyü } \\
\hline Avena sterilis & Poaceae & Tek Y1llık & İstilac1 & 8.5 \\
\hline Bromus tectorum & Poaceae & Tek Y1llık & İstilacı & 17.6 \\
\hline Centaurea solstitialis & Asteraceae & Tek Y1llık & İstilacı & 3.9 \\
\hline Hirschfeldia incana & Brassicaceae & Tek Y1llık & İstilacı & 4.7 \\
\hline Lolium rigidum & Poaceae & Tek Y1llık & İstilacı & 11.9 \\
\hline Trifolium cherleri & Fabaceae & Tek Y1llık & İstilacı & 0.9 \\
\hline Trifolium scabrum & Fabaceae & Tek Y1llik & İstilac1 & 7.5 \\
\hline Torilis leptocarpa & Umbelliferae & Çok Yillık & İstilac1 & 25.8 \\
\hline Onopordum carduchorum & Asteraceae & İki Y1llık & İstilac1 & 4.1 \\
\hline Ainsworthia trachycarpa & Apiacea & Tek Yillık & İstilac1 & 15.1 \\
\hline
\end{tabular}

alan oranının diğer meralara göre daha yüksek olması, bu merada taban suyunun diğer meralardan daha yüksek olması ile açıklanabilir. Ayrıca, Kalkan ve Selman köylerinde bitki ile kaplı alan 
oranının düşük olmasının nedeni olarak, adı geçen meralar üzerindeki yoğun otlatma baskısının bir sonucu olduğu düşünülmektedir. İncelenen meralar için saptanan bitki ile kaplı alan oranı değerleri Çınar (2001)'ın, Çukurova'nın yüksek kesimlerinde; Şen (2010)'in, Kiliste; Ağın ve Kökten (2013)'in, Bingöl ili Yedisu ilçesinde; İnal ve ark. (2011) ve Çınar ve ark. (2014)'nın, Hatay'ın taban meralarında saptadıkları bitki ile kaplılık oranı değerlerinden daha düşük bulunmuştur.

Tablo 2. İncelenen meraların bitki örtüsü özellikleri

\begin{tabular}{|c|c|c|c|c|}
\hline \multirow[b]{2}{*}{ Köy adı } & \multirow{2}{*}{$\begin{array}{l}\text { Bitki ile } \\
\text { kaplı alan } \\
\text { oranlar1 } \\
(\%)\end{array}$} & \multicolumn{3}{|c|}{$\begin{array}{c}\text { Botanik kompozisyondaki } \\
\text { oranlar1 }(\%)\end{array}$} \\
\hline & & $\begin{array}{c}\text { Buğdaygil } \\
\text { bitkileri }\end{array}$ & $\begin{array}{l}\text { Baklagil } \\
\text { bitkileri }\end{array}$ & $\begin{array}{c}\text { Diğer } \\
\text { familya } \\
\text { bitkileri }\end{array}$ \\
\hline Ayal1 & $58.88 \mathrm{a}$ & $37.45 \mathrm{a}$ & $39.31 \mathrm{a}$ & $23.24 \mathrm{e}$ \\
\hline Baysu & $60.36 \mathrm{a}$ & $32.17 \mathrm{c}$ & $8.67 \mathrm{c}$ & $59.16 \mathrm{a}$ \\
\hline Kalkan & $26.60 \mathrm{c}$ & $27.81 \mathrm{~d}$ & $39.19 \mathrm{a}$ & $33.00 \mathrm{c}$ \\
\hline Konak & $47.04 \mathrm{~b}$ & $34.63 \mathrm{~b}$ & $37.37 \mathrm{a}$ & $28.00 \mathrm{~d}$ \\
\hline Selman & $26.74 \mathrm{c}$ & $35.20 \mathrm{~b}$ & $14.89 \mathrm{~b}$ & $49.91 \mathrm{~b}$ \\
\hline Ortalama & 43.92 & 33.45 & 27.89 & 38.66 \\
\hline
\end{tabular}

Farklı harfler ile gösterilen sonuçlar LSD testine göre $\mathrm{P} \leq 0.05$ düzeyinde önemlidir.

İncelenen meralarda botanik kompozisyondaki buğdaygillerin ortalama oran1, \% 33.45; baklagillerin ortalama oran1, \% 27.89 ve diğer familyaların oranı da, \% 38.66'dır. Tüm parametrelerde incelenen meralar arasındaki farklılık istatistiksel olarak önemli bulunmuştur. Botanik kompozisyondaki en yüksek buğdaygillerin oranı \% 37.45 ile Ayalı köyü merasında, en düşük buğdaygil oranı \% 27.81 ile Kalkan köyü merasında tespit edilmiştir (Tablo 2). Ülkemiz doğal meralarında yapılan benzer çalışmalarda botanik kompozisyondaki buğdaygillerin oranını Erkun (1972), \% 56; Gökkuş (1984), \% 57; Çınar ve ark. (2005), \% 47.9; Uslu ve Hatipoğlu (2007), \% 69.3; Babalık ve Sönmez (2010), \% 52.48; Ağın ve Kökten (2013), \% 51.7; Çaçan ve Kökten (2014), $\% 29.61$ olarak saptamıştır.

Botanik kompozisyondaki en yüksek baklagillerin oranı \% 39.31 ile Ayalı köyü merasında, en düşük baklagil oranı ise \% 8.67 ile Baysu köyü merasında saptanmıştır (Tablo 2). Baysu köyü merası ile yine kısmen de olsa Selman köyü merasında baklagil türlerinin az olmasının temel nedeni, bu meralarda yoğun olarak küçükbaş hayvanların otlatılmasıdır. Nitekim, taban suyu seviyesinin daha yüksek olduğu Baysu merasında \% 2.3 oranıla Astragalus plumosus, Selman köyü merasında ise Trifolium cherleri ve Trifolium scabrum (sırasıly \% 0.9 ve \% 7.5) türleri dişında herhangi bir baklagil türü bulunmaması (Tablo 1) bu durumu açıkça ortaya koymaktadır. Benzer çalışmalarda botanik kompozisyondaki baklagillerin oranını Bakır (1963), \% 14.0; Gökkuş (1984), \% 7.8; Çınar ve ark. (2005), \% 13.5; Uslu (2005), \% 17.4; Türker (2006), \% 9.29; Uslu ve Hatipoğlu (2007), \% 9.2; Buzuk (2008), \% 8.6; Babalık ve Sönmez (2010), \% 9.15 ve Şen (2010), \% 15.0 olarak saptamıştır.

Botanik kompozisyondaki en yüksek diğer familya oranı \% 59.16 ile Baysu köyü merasında, en düşük diğer familya oranı ise \% 23.24 ile Ayalı köyü merasında tespit edilmiştir (Tablo 2). Araştırmada diğer familya oranı ile ilgili elde edilen bulgular; Çınar ve ark. (2005), Türker (2006), Buzuk (2008), Babalık ve Sönmez (2010) ve Çınar ve ark. (2014)'nın bulguları ile benzerlik göstermektedir.

Samsun yöresinde engebeli bir merada yürütülen çalışmada; buğdaygil, baklagil ve diğer familyalara giren bitkilerin botanik kompozisyona katılma oranlarını sirasıyla \% 30.53, \% 37.73 ve \% 31.94 olarak bildirilmiştir (Ayan, 1997). Lâdik'te yapılan bir başka araştırmada ise buğdaygil, baklagil ve diğer familyalara giren bitkilerin botanik kompozisyona katılma oranları sirasıly \% 8.90, \% 68.23 ve \% 22.87'dir (Aydın ve Uzun, 2000). Mardin'in Derik ilçesinde yer alan bir merada yürütülen araştırma sonuçlarına göre; mera alanının \% 53.25'inin bitki ile kaplı alan olduğu ve kaplama alanına göre botanik kompozisyonun \% 4.00'ünün buğdaygillerin, $\%$ 23.22'sinin baklagillerin ve \% 72.78'inin de diğer familya bitkilerinin oluşturduğu belirlenmiştir (Aydın ve ark., 2014).

Araştırma sonucunda; bitki ile kaplı alan ve botanik kompozisyondaki buğdaygil, baklagil ve diğer bitki familyalarının oranı bakımından elde edilen bulgular, birçok ekolojik şartlarda yürütülen çalışmalar ile benzerlik ve farklılıkları bulunmaktadır. Bulgular arasındaki bu farklılıklar; vejetasyon ölçümünde kullanılan yöntemlerin farklılığından kaynaklanmasının yanı sıra; incelenen meralar arasındaki toprak, iklim ve özellikle yağış rejiminin farklılığından ve aynı zamanda otlatma baskısı ve otlayan hayvanların cinsinin farklı olmasından kaynaklandığ söylenebilir.

\section{Sonuçlar}

Sonuç olarak, Diyarbakır iline bağlı Eğil ilçesinin 5 farklı köy merasında yapılan vejetasyon etütlerine göre; incelenen mera vejetasyonlarının tamamen istilacı türlerden oluştuğu ve bu nedenle de meraların çok zayıf mera olduğu belirlenmiştir. Mera alanlarında görülen bu sorunların giderilmesi 
için bir taraftan otlatmanın amenajman kurallarına uygun olarak yapılması, diğer taraftan adı geçen alanların uygun metotlarla 1slah edilmesi gerekmektedir. Gerekli görüldüğü durumlarda ise suni mera tesisinin gündeme alınması da unutulmamalıdir.

\section{Teşekkür}

Bu çalışma Gıda Tarım ve Hayvancılık Bakanlığg, Bitkisel Üretim Genel Müdürlüğü (BÜGEM) tarafindan desteklenen "Ulusal Mera Kullanım ve Yönetim Projesi” kapsamında yapılmıştır. Desteklerinden dolayı BÜGEM'e, bitki teşhislerini yapan Dicle Üniversitesi Fen Edebiyat Fakültesi Biyoloji Bölümü Öğretim Üyesi Prof. Dr. Alaattin Selçuk ERTEKINN'e teşekkürlerimizi sunarız.

\section{Kaynaklar}

Ağın, Ö., Kökten, K., 2013. Bingöl ili Yedisu ilçesi Karapolat köyü merasının botanik kompozisyonunun belirlenmesi. Türk Doğa ve Fen Dergisi, 1(2): 41-45.

Altın, M., Gökkuş, A., Koç, A., 2005. Çayır ve Mera Islahı. T.C. Tarım ve Köyişleri Bakanlığı, Tarımsal Üretim ve Geliştirme Genel Müdürlüğü, Çayır-Mera ve Havza Geliştirme Dairesi Başkanlığı, Ankara.

Anonim, 2008. Türkiye'nin Çayır ve Mera Bitkileri. T.C. Tarım ve Köyişleri Bakanlığı, Ankara.

Avağ, A., Mermer, A., Yıldız, H., Ünal, E., Urla, Ö., Aydoğdu, M., Dedeoğlu, F., Aydoğmuş, O., Torunlar, H., Tuğaç, M.G., Ünal, S., Mutlu, Z., Özaydın, K.A., Özgöz, M.M., Aksakal, E., Kara, A., Uzun, M., Çakal, Ş., Yıldırım, T., Aksoyak, Ş., Tezel, M., Aygün, C., Kara, İ., Erdoğdu, İ., Sever, L., Atalay, A., Yavuz, T., Avcı, M., Çınar, S., İnal, İ., Yücel, C., Cebel, H., Keçeci, M., Başkan, O., Depel, G., Patla, Ç., Çarkacı, A., Karadavut, U., Şimşek, U., Sürmen, M., Odabaşı, G., Gül, D., Koç, A., Erkovan, H.İ., Güllapoğlu, K., Kendir, H., Şahin, N., 2012. TUBİTAK 106G017 nolu Ulusal Mera Kullanımı ve Yönetim Projesi Sonuç Raporu. Ankara.

Ayan, İ., 1997. Samsun yöresi engebeli meralarında değişik 1slah yöntemlerinin etkileri üzerinde bir araştırma. Doktora tezi, Ondokuz Mayıs Üniversitesi Fen Bilimleri Enstitüsü, Tarla Bitkileri Anabilim Dalı, Samsun.

Aydın, İ., Uzun, F., 2000. Ladik ilçesi Salur köyü merasında farklı 1slah metotlarının ot verimi ve botanik kompozisyon üzerine etkileri. Turkish Journal of Agriculture and Forestry, 24: 301-307.

Aydın, A., Çaçan, E., Başbağ, M., 2014. Mardin ili Derik ilçesinde yer alan bir meranın botanik kompozisyonunun belirlenmesi. Türk Tarım ve Doğa Bilimleri Dergisi, Özel Sayısı, 2: 1625-1630.

Babalık, A.A., Sönmez, K., 2010. Isparta ili Bozanönü köyü Kırtepe merasında botanik kompozisyonun belirlenmesi üzerine bir araştırma. Bartın Orman Fakültesi Dergisi, 12(17): 27-35.

Bakır, Ö., 1963. ODTÜ Arazisinde Bir Mera Etüdü. Ankara Üniversitesi Ziraat Fakültesi Yayınları, No: 382, Ankara.

Bakoğlu, A., Koç, A., 2002. Otlatılan ve korunan iki farklı mera kesiminin bazı toprak ve bitki örtüsü özelliklerinin karşılaştırılması. I. Bitki örtüsü özelliklerinin karşılaştırılması. Fırat Üniversitesi Fen ve Mühendislik Bilimleri Dergisi, 14(1): 37-47.

Başbağ, M., Çelik, M.A., 2001. Diyarbakır ili Gözalan köyünde korunan ve otlatılan meralardaki bitki tür ve kompozisyonları ile ot verimlerinin incelenmesi üzerine bir araștırma. Türkiye IV. Tarla Bitkileri Kongresi, Cilt: III, 17-21 Eylül, Tekirdağ, s. 187192.

Buzuk, G., 2008. Van ili Çaldıran ilçesi meralarının botanik kompozisyonları ve ot verimleri üzerine bir araştırma. Yüksek lisans tezi, Yüzüncü Y1l Üniversitesi Fen Bilimleri Enstitüsü, Van.

Christiansa, M.S., Den Hoen, G., 1979. Grassen En Schijgrassen in Kleur, Politikans Forlag A/S, Kolenhavn.

Çaçan, E., Kökten, K., 2014. Bingöl ili Merkez ilçesi Çiçekyayla köyü merasının ot verimi ve otlatma kapasitesinin belirlenmesi. Türk Tarım ve Doğa Bilimleri Dergisi, Özel Sayı, 2: 1727-1733.

Çınar, S., 2001. Adana ili Tufanbeyli ilçesi Hanyeri köyü merasında verim ve botanik kompozisyonun saptanması üzerine bir araştırma. Yayınlanmamış yüksek lisans tezi, Çukurova Üniversitesi Fen Bilimleri Enstitüsü, Adana.

Çınar, S., Avcı, M., Hatipoğlu, R., Kökten, K., Atış, İ., Tükel, T., Aydemir, S., Yücel, H., 2005. Hanyeri Köyü (Tufanbeyli-Adana) merasının yamaç kesiminde farklı azot ve fosfor dozlarının botanik kompozisyon, ot verimi ve ot kalitesine etkileri üzerinde araştırma. Türkiye 6. Tarla Bitkileri Kongresi, 5-9 Eylül, Antalya, s: 873-877.

Çınar, S., Hatipoğlu, R., Avcı, M., İnal, İ., Yücel, C., Avağ, A., 2014. Hatay ili Kırıkhan ilçesi taban meraların vejetasyon yapısı üzerine bir araştırma. Gaziosmanpaşa Üniversitesi Ziraat Fakültesi Dergisi, 31(2): 52-60.

Çomaklı, B., Menteşe, Ö., 1999. Mera ıslahını gerektiren nedenler. T.C. Orman Bakanlığı, Ağaçlandırma ve Erozyon Kontrolü Genel Müdürlüğü, Doğu Anadolu $\mathrm{Su}$ Havzaları Rehabilitasyon Projesi, Mera Islahı Eğitim Uygulama Semineri, 28-30 Haziran, Erzurum, s. 1-9.

Davis, P.H., 1969. Flora of Turkey and the Eastaege an Islands. University of Edinburgh Press, Volume 1-3, Edinburgh.

De Vries, D.M., De Boer, T.A., Dirver, J.P.P., 1951. Evaluation of grassland by botanical research in the Netherlands. Proceedings of the United Nationals Scientific Conference on the Conservation and Utilization of Resources, NY, 6: 522-524.

Değirmenci Karataş, D., Karataş, H., Özdemir, G., 2015. Diyarbakır İli Bağcılığının Sektörel Durum Analizi. 
Dicle Üniversitesi Ziraat Fakültesi Bahçe Bitkileri Bölümü, Diyarbakır. http://www.dicle.edu.tr/ Contents/179a0cce-e7e0-46a1-bc29-9a815bd220a4. pdf (Erişim tarihi: 18.05.2015).

Demiri, M., 1983. Flora Ekskursioniste e Shqiperise. Tiranë.

Edgecombe, W., 1964. Weeds of Lebanon. Faculty of Agriculture Sciences American University of Beirut, Lebanon, Publication No: 24.

Erkun, V., 1972. Bala ilçesi meraları üzerinde araştırmalar. Tarım Bakanlığı, Hayvancılığı Geliştirme Genel Müdürlüğü Yayınları, Ankara.

Garms, H., Eigener, W., Melderis, A., Pope, T., Durrell, G., 1968. The Natural History of Europe. Paol Hamilyn Limited, London.

Gökkuş, A., 1984. Değişik 1slah yöntemleri uygulanan Erzurum tabii meralarının kuru ot ve ham protein verimleri ile botanik kompozisyonları üzerinde araştırmalar. Yayınlanmamış doktora tezi, Atatürk Üniversitesi Ziraat Fakültesi Tarla Bitkileri Bölümü, Erzurum.

Gökkuş, A., Koç, A., Çomaklı, B., 2000. Çayır-Mera Uygulama Kılavuzu. Atatürk Üniversitesi Ziraat Fakültesi Yayınları No: 142, Erzurum.

Hitchcock, A.S., 1950. Manual of the Grasses on the United States. United States Department of Agriculture. Second Edition, Miscellaneous Publication, No: 200, USA.

Holechek, J.L., Pieper, R.D., Herbel, C.H., 2004. Range Management: Principles and Practices. Pearson/Prentice-Hall, UpperSaddle River, New Jersey.

Huxley, A., Taylor, W., 1977. Flowers of Greece and the Aegean, Chatto and Windus Ltd. Printed Great Britain by Richard Clay Ltd. Bunges, Suffolk.

İnal, İ., Avcı, M., Çınar, S., Yücel, C., Hatipoğlu, R., 2011. Çukurova Bölgesi sahil meralarının vejetasyon yapısı üzerine bir araştırma. IX. Tarla Bitkileri Kongresi, Sunulu Bildiri, 3. Cilt, 12-15 Eylül, Bursa, s. 1664-1667.

Koç, A., Çakal, Ş., 2004. Comparison of some rangeland canopy coverage methods. International Soil Congress Natural Resource Management for Sustaiable Development, 7-10 June, Erzurum, Türkiye, s. 41-45.

Kürschner, H., Raus, T., Venter, J., 1995. Pflanze der Türkei. Quelle and Meyer Verlag, Werbada.

Needon, C., Petermann, J., Scheffel, P., Scheibo, B., 1989. Grasser Naturführer in Farbe. Pflanza and Tiere-Gondrom Verlog, Bayreuth.

Okatan, A., 1987. Trabzon-Meryemana deresi yağış havzası alpin meralarının bazı fiziksel ve hidrolojik toprak özellikleri ile vejetasyon yapısı üzerine araștırmalar. Tarım Orman ve Köyișleri Bakanlığ 1 Orman Genel Müdürlüğü Yayınları, Yayın No: 664, Seri No: 62, Ankara.

Öztan, Y., Okatan, A., 1985. Çayır-Mera Baklagil ve Buğdaygil Yem Bitkilerinin Tanıtım Kılavuzu. Cilt II, Karadeniz Teknik Üniversitesi Orman Fakültesi, Karadeniz Üniversitesi Basımevi, Genel Yayın No: 95, Fakülte Yayın No: 8, Trabzon.

Pohl, R., 1968. The Grasses Library of Congress Catalog, Card Number: 54-1268, W.M.C. Brown Company Publishers, Dubuque, Iowa.

Polunin, O., Huxley, A., 1974. Flowers of the Mediterranean, Chatto and Windus, London.

Şen, Ç., 2010. Kilis ili bazı köylerindeki meralarda vejetasyon yapısı üzerine bir araştırma. Yayınlanmamış yüksek lisans tezi, Çukurova Üniversitesi Fen Bilimleri Enstitüsü, Adana.

Türker, A.H., 2006. Mersin-Tarsus Oluk Koyak köyü Topak Ardıç mevkisinde 1997 yılından beri korunmuş ağaçlandırma sahasındaki otsu vejetasyonun özellikleri üzerine bir araștırma. Yüksek lisans tezi, Çukurova Üniversitesi Fen Bilimleri Enstitüsü Tarla Bitkileri Anabilim Dalı, Adana.

Uslu, Ö.S., 2005. Kahramanmaraş ili Türkoğlu ilçesi Araplar köyü Yeni Yapan merasında botanik kompozisyonun tespiti ve farklı gübre uygulamalarının meranın verim ve botanik kompozisyonuna etkileri üzerinde araştırmalar. Yayınlanmamış doktora tezi, Çukurova Üniversitesi Fen Bilimleri Enstitüsü, Adana.

Uslu, Ö.S., Hatipoğlu, R., 2007. Kahramanmaraş ili Türkoğlu ilçesi Araplar köyü Yeni Yapan merasında botanik kompozisyonun tespiti üzerine bir araștırma. Türkiye VII. Tarla Bitkileri Kongresi, 25-27 Haziran, Erzurum, s. 181-184.

Weymer, H., 1981. Lernt Pflanze Kenen. Ferdinand Enke Verlag, Stuttgart.

Yavuz, T., Sürmen, M., Töngel, M.Ö., Avağ, A., Özaydın, K.A., Yıldız, H., 2011. Samsun ili meralarının vejetasyon özellikleri. Türkiye 9. Tarla Bitkileri Kongresi, Çayır Mera Yem Bitkileri, Cilt III, 12-15 Eylül, Bursa, s: 1773-1778.

Yavuz, T., Sürmen, M., Töngel, M.Ö., Avağ, A., Özaydın, K.A., Yıldız, H., 2012. Amasya mera vejetasyonlarının bazı özellikleri. Tarım Bilimleri Araştırma Dergisi, 5(1): 181-185.

Yurtsever, N., 1984. Deneysel İstatistik Metotları. Köy Hizmetleri Genel Müdürlüğü Yayınları, Genel Yayın No: 121, Ankara. 